УДК 351:342.97

\author{
Товмасян Артур, \\ ORCID iD 0000-0003-2615-4692 \\ E-mail: artur-1981@ukr.net
}

\title{
ПРОБЛЕМИ ЗАБЕЗПЕЧЕННЯ НАЛЕЖНОГО ВИКОНАННЯ СУДОВИХ РІШЕНЬ ЩОДО СУБ'ЄКТІВ ГОСПОДАРЮВАННЯ В УКРАЇНІ: ДЕРЖАВНО-УПРАВЛІНСЬКИЙ ВИМІР
}

https://doi.org/10.32689/2618-0065-2020-4(6)-252-265

Анотація. Належне виконання судових рішень $є$ виявом довіри до органів державної влади, а також однією 3 умов взаємовигідної співпраці суб'єктів господарювання. Узагальнення даних офіційної статистики, матеріалів соціологічних досліджень, змісту дисертаційних робіт і публікацій у фахових виданнях за даною проблематикою дозволяє стверджувати про наявність як фрагментарних, так $\mathrm{i}$ комплексних досліджень, спрямованих на виявлення причин доволі низької результативності державного управління виконання судових рішень щодо суб'єктів господарювання в Україні. Загалом невтішна ситуація обумовлена наявністю декількох проблем, які істотною мірою ускладнюють умови забезпечення економічної безпеки як окремих суб'єктів господарювання, так і територій загалом. Для вирішення чи, принаймні, мінімізації негативного впливу проблем, потрібне чітке розуміння їх специфіки, а тому доречною вбачається вдосконалена класифікація проблем, що унеможливлюють забезпечення належного рівня результативності державного управління виконанням судових рішень щодо суб'єктів господарювання в Україні залежно від масштабу, особи позивача, особи відповідача, специфіки позову, економічного становища позивача, етапу примусового виконання судових рішень щодо суб'єктів господарювання, сфери застосування відповідних 


\section{Науковий вісник: Державне управління № 4(6)2020}

механізмів державного. Пропонована класифікація не містить вичерпного їх переліку, оскільки на тлі вирішення «старих», цілком ймовірна поява «нових» проблем. Запропонована класифікація має доповнити методологію державного управління, a ii використання дозволить більш системно підходити до розробки конкретних рекомендацій по усуненню наявних проблем у цій царині. Подальші наукові розвідки за даною проблематикою мають бути спрямовані на розробку для підрозділів Державної виконавчої служби та приватних виконавців практичних рекомендацій, що передбачають вдосконалення наявних $\mathrm{i}$ запровадження нових механізмів взаємодії у ланцюгу «державний/приватний виконавець - позивач - відповідач» як запоруки підвищенню довіри до системи виконання судових рішень, й (що більш важливо) покращенню умов для ведення легального бізнесу.

Ключові слова: державне управління, судові рішення, примусове виконання, суб'єкти господарювання, проблеми.

Постановка проблеми. Належне виконання судових рішень $є$ виявом довіри до органів державної влади, а також однією 3 умов взаємовигідної співпраці між суб'єктами господарювання. Проте дослідження стану справ у цій царині в Україні дозволяе стверджувати про наявність доволі низької результативності державного управління виконання судових рішень щодо суб'єктів господарювання. Тому не дивно, що «...76,7\% респондентів незадоволені діями державних виконавців, а 44,0 \% опитаних громадян визнали діяльність Державної виконавчої служби (далі - ДВС) України на сучасному етапі неефективною» $[4$, с. 16]. «...70,0 \% судових рішень не виконуються» [6]; «...z 100 млрд, які стягуються господарськими судами щорічно, так i залишаються «підвішеними» й невиконаними» [10, с. 49]. Зрештою варто погодитись, що «влада не надто переймалася цією проблемою, a усі іiі кроки у напрямі вдосконалення правосуддя та суміжних правових інститутів, дотепер мали виключно декларативний 
характер» [5, с. 14]. Означена (загалом невтішна) ситуація обумовлена наявністю деяких проблем, без вирішення яких вкрай складно розраховувати на економічну безпеку як окремих суб'єктів господарювання, так і територій у цілому. Запорукою забезпечення дотримання правових норм має передувати систематизація наявних проблем, що й обумовлює актуальність даного дослідження.

Аналіз останніх досліджень і публікацій. Окремі аспекти ролі держави в забезпеченні примусового виконання судових рішень щодо суб'єктів господарювання знайшли своє місце як в дисертаційних дослідженнях, так і в наукових публікаціях. Так, зокрема, О. Бущан такими проблемами визначає: «недосконалий механізм виконання таких рішень; правові колізіі; постійний тиск на виконавця 3 боку всіх зацікавлених сторін» [1, с. 94]. С. Гришко - до проблем, які залишилася невирішеними відносить «невиконання рішень судів боржником, за якими виступає держава» [2, с. 67]; «структура органів ДВС не відповідає визначеним критеріям» [2, с. 115]. На переконання Р. Калініна, «недоліком процедури здійснення виконавчого провадження є відсутність механізмів звернення стягнення на корпоративні права боржника» [3, с. 198]. Л. Крупнова виділила такі «...конструктивні недоліки сучасної реформи системивиконавчого провадження: відсутність ефективних механізмів контролю за суб'єктами делегованих повноважень (приватними виконавцями); нерозвиненість міжнародного співробітництва у сфері виконавчого провадження; ігнорування владою низького рівня правової культури суспільства при реформуванні системи примусового виконання рішень; відсутність положень щодо підвищення ролі інститутів громадянського суспільства у державному управлінні; недосконалість механізмів притягнення виконавців до відповідальності за протиправні дії або бездіяльність...» [4, с. 7-8]; «...відсутність чіткого розмежування видів юрисдикційних рішень i закріплення обов'язку щодо їх виконання за конкретними суб'єктами...» 
Науковий вісник: Державне управління № 4(6)2020

[4, с. 10]. При цьому А. Мілевська та Д. Ліхтанська небезпідставно припускають, що «...практика приватного виконавця може стати «узаконеним рейдерством», оскільки всі теперішні колектори негайно перейдуть до лав приватних виконавців i почнуть, прикриваючись законом, порушувати права і свободи громадян. За відсутності чітких механізмів контролю за цими суб'єктами така ситуація є імовірною...» [8, c. 32]. Проте, для пошуку кращих варіантів підвищення результативності примусового виконання судових рішень щодо суб'єктів господарювання, замало фрагментарних досліджень. Тому неабиякий інтерес викликають результати дослідження, в якому М. Мальський розглянув «основні підстави, що призводять до невиконання судових рішень, i провів їх розмежування та класифікацію за такими критеріями: воля боржника (суб'єктивні та об'єктивні підстави невиконання рішень); стадія виникнення підстави невиконання (після винесення рішення чи іншого акту, що підлягає виконанню, але до звернення до органів примусового виконання; відкриття виконавчого провадження; здійснення виконавчих дій, якщо рішення не було виконане в строк, наданий для добровільного виконання, та після початку процедури його примусового виконання відповідним органом; залучення до виконання інших суб'єктів і реалізації їх функції; задоволення вимог кредитора; закінчення виконавчого провадження або повернення виконавчого документа стягувачеві); об'єкт, щодо якого виникає проблема (майно; валютне та фінансове регулювання; особа боржника; діяльність органів примусового виконання; законодавчі положення; акт, що підлягає примусовому виконанню); юрисдикція виникнення проблем (національний режим регулювання; режим регулювання іноземної держави; положення міжнародних угод)» [6, с. 46-49]. Принагідно варто погодитись, що «одна й та ж підстава невиконання судових рішень може бути характерною одразу для декількох груп класифікації» [6, с. 49]. 
Науковий вісник: Державне управління № 4(6)2020

Метою статті є систематизація проблем зі забезпеченням належного виконання судових рішень щодо суб'єктів господарювання в Україні.

Методи дослідження. Аналіз та синтез - для виявлення проблем, що ускладнюють забезпечення належного виконання судових рішень щодо суб' єктів господарювання. Абстрактнологічний - для теоретичних узагальнень і формулювання висновків.

Виклад основного матеріалу. Узагальнення результатів аналізу чинної нормативно-правової бази, напрацювань провідних науковців i практиків, а також результати власних досліджень у цій царині дозволяють вдосконалити класифікацію проблем, що унеможливлюють забезпечення належного рівня результативності державного управління виконанням судових рішень щодо суб'єктів господарювання в Україні залежно від:

1. Масштабу: міжнародний; країна, регіон, населений пункт; національна економіка, ii галузь/сфера; суб'єкт господарювання.

2. Позивача: держава; орган державного управління, орган місцевого самоврядування; юридична особа; фізична особа.

3. Відповідача: держава; орган державного управління, орган місцевого самоврядування, їхні посадові та службові особи; юридична особа; фізична особа.

4. Специфіки позову: безперечний, спірний.

5. Економічного становища відповідача: платоспроможний, банкрут.

6. Етапу примусового виконання судових рішень щодо суб'єктів господарювання: прецедентний, досудовий, судовий, виконавчий, поствиконавчий.

7. Сфери застосування відповідних механізмів державного управління:

адміністративна: відсутність системного та послаблення судового контролю за діяльністю ДВС і приватних виконавців; можливість накладення арешту на майно декількома 


\section{Науковий вісник: Державне управління № 4(6)2020}

виконавцями; недосконалість механізмів притягнення виконавців до відповідальності за протиправні дії або бездіяльність; обмеженість пересування (в'їд/виїзд) іноземців, а також брак їхнього майна в Україні; постійний тиск на виконавця з боку всіх зацікавлених сторін;

економічна: брак коштів на рахунках боржників i недостатність бюджетного фінансування для виконання судових рішень проти державних органів чи державних компаній; визначення та переказ суми за рішенням іноземного суду, що визначена в іноземній валюті; відсутність дієвих механізмів компенсації за затримки виконання судових рішень; відсутність обов'язку суду штрафувати винну особу за невиконання судового рішення в адміністративній справі; зниження ціни нереалізованого майна до 50 \% від початкової вартості; можливість отримання додаткової винагороди приватним виконавцем відповідно до його угоди зі стягувачем; неврегульованість механізму звернення стягнення на дебіторську заборгованість; неврегульованість механізму стягнення коштів органами доходів i зборів у рахунок погашення податкового боргу; недостатність фінансування діяльності органів ДВС; недостатня визначеність механізмів звернення стягнення на земельні ділянки, майнові права боржника та його депозити; незацікавленість державних виконавців у своєчасному, повному та неупередженому примусовому виконанні рішень; неможливість звернення стягнення на майно держави або банкрутства компаній, що належать державі відповідно до мораторію на примусовий продаж майна; неможливість переказу коштів у добровільному порядку до видачі іноземним судом виконавчого документа; неможливість приєднання будь-якого майна, розташованого в Чорнобильській зоні, без спеціального дозволу держави; неналежне забезпечення умов праці судових виконавців;

інституційна: відокремлення виконавчої служби від судової системи й підпорядкування ії органу виконавчої влади; відсутність базової юридичної освіти (особливо спеціалізованої 
3 нормотворчої (законотворчої) діяльності) у переважної більшості розробників законопроєктів; відсутність доступу до АСВП помічників приватних виконавців; відсутність зв'язку між метою адміністративно-правового регулювання системи виконавчого провадження та суспільним призначенням цього інституту; відсутність механізму передачі виконавчого провадження 3 одного органу ДВС до іншого; існування «нового» та «старого» реєстру прав на нерухоме майно; можливість одночасного проведення виконавчих дій кількома виконавцями (державними та/або приватними) щодо одного боржника; надмірне навантаження на державних виконавців («середня норма надходжень виконавчих документів до одного виконавця становить майже кілька тисяч документів на рік» [5, с. 124]); невирішеність питання щодо подальшого пред'явлення стягувачем нових виконавчих документів до виконавців, які відрізняються своїм статусом (державні/приватні) та територіальною приналежністю; недосконалість структури органів ДВС; недостатня визначеність правового становища суб'єктів виконавчого провадження (відсутність чіткого розмежування адміністративно-правового статусу державного та приватного виконавців); недостатня пристосованість організаційної структури ДВС до вимог сьогодення; незрозумілість місця органів примусового виконання та приватних виконавців у механізмі виконання рішень за конституційними скаргами громадян; необхідність погодження виконавчих дій державного виконавця начальником відповідного органу ДВС, так і окремих процедур із вищим органом ДВС; припинення діяльності юридичної особи та/або фіктивне банкрутство; системні недоліки у взаємодії виконавців 3 іншими державними та недержавними установами; функції організації діяльності органів ДВС, координації та контролю дублюються органами ДВС і органами юстиції;

організаційна: визнання та виконання рішення, винесеного щодо кількох боржників; доволі тривалий строк провадження 
щодо примусового виконання рішення, а також визнання іноземного або арбітражного рішення в Україні; зміна місцеперебування боржника/виїзд за кордон; недопущення виконавця до майна; недостатня відкритість і прозорість процедури реалізації арештованого майна боржника; неможливість перегляду Верховним Судом України рішень несудового міжнародного органу; нерозвиненість міжнародного співробітництва у сфері виконавчого провадження; нехтування національними здобутками матеріального й процесуального права та доведення до абсурду запозичення закордонного (зокрема, європейського) досвіду; обрання державним виконавцем на власний розсуд процесуальних засобів для примусового виконання рішення, термінів їх здійснення; обтяження активів відповідача (заборона відчуження, арешт, кількість власників майна, зареєстровані неповнолітні, неможливість виділення цілої частки в натурі, реєстрація майна $\epsilon$ відмінною від його місцезнаходження); оскарження результатів торгів i здійснення реституції за угодами, укладеними за результатами прилюдних торгів; порушенням процесуальних норм (неповідомлення учасників виконавчого провадження про час $\mathrm{i}$ місце судового засідання щодо розгляду позову...); труднощі по залученню перекладача (підтверджена належна кваліфікація, непоширена іноземна мова) та правова невизначеність щодо залучення спеціаліста; умисне процесуальне затягування (мирова угода на етапі виконання та iii подальше недотримання, оскарження дій виконавця, оскарження оцінки майна або торгів, зупинення виконавчого провадження тощо);

правова: відсутність балансу між принципом «дозволено все, що не заборонено» для учасників господарських відносин i принципом «дозволено лише те, що прямо передбачено законом» для такого «неусувного» та обов'язкового елемента (учасника) виконавчого провадження, як державна структура орган (посадова особа) Державної виконавчої служби України; 
Науковий вісник: Державне управління № 4(6)2020

відсутність законодавчого закріплення системи особливих заходів державного захисту державних і приватних виконавців від перешкоджання виконанню службових обов'язків і від посягання на життя, здоров'я, житло й майно цих осіб та їхніх близьких родичів у зв'язку зі службовою діяльністю; відсутність положень щодо запобігання незаконного втручання у хід виконавчого провадження, правові колізії (відсутня індивідуалізація суб'єктів, які здійснюють незаконне втручання у виконавче провадження, немає деталізації видів такого втручання, а також наслідків цієї протиправної діяльності); застосування більш обтяжувальних положень національного законодавства щодо надання суду документів, ніж це передбачено міжнародними договорами; наявність у процесуальних нормах оцінювальних понять, застосування яких вимагає ретельного дослідження обставин справи та надання належного обгрунтування у судовому рішенні (як-то: поважні причини пропуску строку, ухилення від виконання зобов'язань за рішенням суду, чинення боржником перешкод державному виконавцю у доступі до житла); невизначеність щодо віднесення рішення Конституційного Суду України до переліку юрисдикційних рішень, які підлягають примусовому виконанню, або ж воно матиме окремий статус і специфічні механізми виконання; неможливість добровільного виконання державою рішень міжнародних органів, юрисдикція яких визнана Україною (крім рішень ССПЛ); орієнтування чинного законодавства не на стягувача й захист його прав (тобто не на доктрину безумовного i невідворотного виконання рішень суду), а здебільшого на боржника (особу, яка вже апріорі вчинила порушення законодавства, не виконавши своїх зобов’язань і призвівши до руйнації господарських зв'язків); розширення законодавчих положень у підзаконних актах, продовження дії підзаконних актів, прийнятих ще на підставі законів, що втратили чинність; неврегульованість повноважень окремих підрозділів і посадових осіб органів ДВС в Україні; 
Науковий вісник: Державне управління № 4(6)2020

соиіально-психологічна: ігнорування владою низького рівня правової культури суспільства при реформуванні системи примусового виконання рішень; низька престижність професії державного виконавця; правова незрілість політичної еліти та суспільства.

Пропонована класифікація не містить вичерпного їх переліку, оскільки на тлі вирішення «старих», цілком ймовірна поява «нових» проблем.

Висновки та напрями подальших досліджень. Без розв'язання наявних проблем 3 належним виконанням судових рішень вкрай складно розраховувати на економічну безпеку як окремих суб'єктів господарювання, так і територій загалом. Для вирішення чи, принаймні, мінімізації негативного впливу проблем, потрібне чітке розуміння їх специфіки, а тому доречною вбачається вдосконалена класифікація проблем, що унеможливлюють забезпечення належного рівня результативності державного управління виконанням судових рішень щодо суб'єктів господарювання в Україні залежно від масштабу, особи позивача, особи відповідача, специфіки позову, економічного становища позивача, етапу примусового виконання судових рішень щодо суб'єктів господарювання, сфери застосування відповідних механізмів державного. Запропонована класифікація має доповнити методологію державного управління, а іiі використання дозволить більш системно підходити до розробки конкретних рекомендацій по усуненню наявних проблем у цій царині. Подальші наукові розвідки за даною проблематикою мають бути спрямовані на розробку для підрозділів ДВС та приватних виконавців практичних рекомендацій, що передбачають вдосконалення наявних i запровадження нових механізмів взаємодії у ланцюгу «державний/приватний виконавець - позивач відповідач» як запоруки підвищення довіри до системи виконання судових рішень, й (що більш важливо) покращенню умов для ведення легального бізнесу. 


\section{Список використаних джерел}

1. Бущан О. А. Сучасні питання державного управління у сфері примусового виконання судових рішень та рішень інших органів. Науковий вісник Міжнародного гуманітарного університету (Серія: Юридичні науки). 2017. № 29. Т. 1. С. 94-97.

2. Гришко Є. М. Державне управління у сфері примусового виконання рішень судів та інших органів влади: дис. ... канд.держ.упр.: 25.00.01. Київ, 2016. 224 с.

3. Калінін Р. С. Адміністративні процедури у виконавчому провадженні за законодавством України: дис. ... канд. юрид. Наук : 12.00.07. Запоріжжя, 2013. 268 с.

4. Крупнова Л. В. Система виконавчого провадження в Україні: теоретико-правові та праксеологічні аспекти : дис. ... д-р юрид. наук: 12.00.07. Дніпро, 2019. 440 с.

5. Макушев П. В. Державна виконавча служба в Україні: адміністративно-правове дослідження: автореф. дис. ... д-р юрид. наук.: 12.00.07. Запоріжжя, 2017. 38 с.

6. Мальський М. М. Основні підстави невиконання судових рішень та інших актів, що підлягають примусовому виконанню в транснаціональному виконавчому процесі. Альманах міжнародного права. 2014. Вип. 6. С. 41-51.

7. Мелех Л. В., Візняк О. В. Проблемні аспекти виконання рішень господарського суду в Україні та шляхи їх удосконалення. Науковий вісник Львівського державного університету внутрішніх справ. 2016. № 4. С. 121-131.

8. Мілевська А. О., Ліхтанська Д. М. Перспективи запровадження інституту приватних виконавців в Україні. Прикарпатський юридичний вісник. 2016. № 5. С. 29-32.

9. Мін'юст презентував реформу системи примусового виконання та створення інституту приватних виконавців. // Вебсайт Міністерства юстиції / Міністерство юстиції України. URL : https://minjust.gov.ua/news/ministry/minyust-prezentuvav-reformusistemi-primusovogo-vikonannya-ta-stvorennya-institutu-privatnihvikonavtsiv-21460. (дата звернення: 11.09.2020). 
Науковий вісник: Державне управління № 4(6)2020

10. Святогор О. А. Правове регулювання виконання рішень господарського суду: постановка проблеми. Економіка та право. 2015. № 2. C. 45-52.

\section{References}

1. Bushshan O. A. (2017). Suchasni pytannya derzhavnoho upravlinnya u sferi prymusovoho vykonannya rishen' sudiv ta rishen' inshikh orhaniv [Feeding of the state administration in the spheres of the Primus Viscounting of the ship's height and the height of the other bodies]. Naukovyy visnyk Mizhnarodnoho humanitarnoho universytetu. (Seriya: Yurydychni nauky). [Science book of the International Humanities University (Series: Legal Sciences)]. 29:1. 94-97. [in Ukrainian].

2. Hryshko Ye. M. (2006). Derzhavne upravlinnya u sferi prymusovoho vykonannya rishen' sudiv ta inshykh orhaniv vlady [The state administration in the sphere of Primus Viscounting is the highest number of courts and other state bodies]: Extendet abstract of candidate's thesis. Kyyiv. [in Ukrainian].

3. Kalinin R. S. (2013). Administratyvni prostedury u vukonavchomu provadzhenni za zakonodavstvom Ukrayiny [Administrative procedures at the legislative level of Ukraine]: Extendet abstract of candidate's thesis. Zaporizhzhya. [in Ukrainian].

4. Krupnova L. V. (2019). Systema vykonavchoho provadzhennya v Ukrayini: teoretyko-pravovi ta prakseolohichni aspekty [The system of enforcement proceedings in Ukraine: theoretical, legal, and praxeological aspects]. Extendet abstract of Doctor's thesis. Dnipro. [in Ukrainian].

5. Makushev P. V. (2017). Derzhavna vykonavcha sluzhba v Ukrayini: administratyvno-pravove doslidzhennya [State enforcement authority in Ukraine: administrative and legal research]. Extendet abstract of Doctor's thesis. Zaporizhzhya. [in Ukrainian].

6. Mal'skyy M. M. (2014). Osnovni pidstavy nevykonannya sudovykh rishen' ta inshykh aktiv, tstso pidlyahayut' prymusovomu vykonannyu $\mathrm{v}$ transnatsionalnomu vykonavchomu protsesi [The main grounds for non-enforcement of court decisions and other acts subject to enforcement in the transnational enforcement process]. Almanakh 
mizhnarodnoho prava - [Almanac of International Law]. 6. 41-51. [in Ukrainian].

7. Melekh L. V. \& Viznyak O. V. (2016). Problemni aspekty vykonannya rishen' hospodars'koho sudu v Ukriyini ta shlyakhy yikh vyrishennya [Problematic aspects of enforcement of commercial court decisions in Ukraine and ways to improve them]. Naukovyy visnyk Lvivs'koho derzhavnoho universytetu vnutrishikh sprav [Scientific Bulletin of Lviv State University of Internal Affairs]. 4. 121-131. [in Ukrainian].

8. Milevs'ka A. O., \& Likhtans'ka D. M. (2016). Perspektyvy zaprovadzhennya instytutu pryvatnykh vykonavtsiv $\mathrm{V}$ Ukrayini [Prospects for the establishment of the Institute of Private Creators in Ukraine]. Prykarpats'kyy yurydychnyy visnyk [Prykarpathian legal visnik]. 5. 29-32. [in Ukrainian].

9. Min'yust prezentuvav reformu systemy prymusovoho vykonannya ta stvorennya instytutu pryvatnykh vykonavtsiv [The Ministry of Justice presented the reform of the enforcement system and the creation of an institution of private enforcers]. Retrived from: https://minjust.gov.ua/news/ministry/minyust-prezentuvav-reformusistemi-primusovogo-vikonannya-ta-stvorennya-institutu-privatnihvikonavtsiv-21460. [in Ukrainian].

10. Svyatohor O. A. (2015). Pravove rehulyuvannya vykonannya rishen' hospodars'koho sudu: postanovka problem [Legal regulation of enforcement of decisions of economic court: statement of a problem]. Ekonomika ta pravo [Economics and law]. 2. 45-52. [in Ukrainian]. 


\section{PROBLEMS WITH ENFORCEMENT OF JUDICIAL JUDGMENTS ON BUSINESS ENTITIES IN UKRAINE: PUBLIC ADMINISTRATION DIMENSION}

Tovmasian Artur, Postgraduate, Department of Law and European Integration, Kharkov regional institute of state administration of National academy of state administration at President of Ukraine, Moskovsky Avenue 75, Kharkiv, Ukraine, 61001, Ukraine, tel: +38 (050) 301-30-06, E-mail: artur1981@ukr.net, https://orcid.org/0000-0003-2615-4692

Abstract. Proper execution of court decisions is a sign of trust in public authorities, as well as one of the conditions for mutually beneficial cooperation of business entities. Generalization of data of official statistics, materials of sociological researches, content of dissertations and publications in specialized editions on this problem allows to assert the presence of both fragmented and complex researches aimed at revealing the reasons of rather low efficiency of state management of execution of judicial decisions concerning business entities in Ukraine. In general, the disappointing situation is due to the presence of a number of problems that significantly complicate the conditions for the economic security of not only individual entities but also territories in general. To solve or at least minimize the negative impact of problems, there needs to be a clear understanding of their specifics, and therefore it is appropriate to improve the classification of problems that make it impossible to ensure the proper level of public administration of court decisions in Ukraine depending on the scale, identity of the plaintiff, identity of the defendant, the specifics of the claim, the economic situation of the plaintiff, the stage of enforcement of court decisions on business entities, the scope of the relevant mechanisms of the state. The proposed classification does not contain an exhaustive list of them, as it is quite possible that new problems will appear against the background of solving old ones. The proposed classification should complement the methodology of public administration, and its use will allow a more systematic approach to the development of specific recommendations to address existing problems in this area. Further research in this area should be aimed at developing practical recommendations for the subdivisions of the public executive service and private executors, which would imply improvement of the existing and introduction of new mechanisms of interaction in the chain of "public/private executor - plaintiff - defendant" as a pledge to increase confidence in the system of enforcement of court decisions, and (more importantly) to improve the conditions for doing legal business.

Keywords: public administration, court decisions, enforcement, business entities, problems. 